\title{
Online Banking Service Quality: A South African E-S-QUAL Analysis
}

\author{
Mathias Mujinga $^{(\mathbb{})}$ (1) \\ School of Computing, University of South Africa, Johannesburg, South Africa \\ mujinm@unisa.ac.za
}

\begin{abstract}
Technologically, competition is fierce in the banking industry, as such, banks need to offer cutting-edge technology and still make sure the banking solutions provided keep customers satisfied, as customers could switch between banks with minimum inconvenience. Electronic service quality measures the level of satisfaction deliver to bank customers through online banking digital solutions. This paper provides an investigation of electronic service quality based on customers' perceptions in South Africa. The paper presents findings based on quantitative data from 184 online banking customers using ES-QUAL measurement scale. The results show that banks are meeting customer expectations of service quality delivery, although there is room for improvement. The study has practical implications to financial institutions in South Africa, as it highlights areas of attention to improve service quality delivered to online banking customers.
\end{abstract}

Keywords: Service quality $\cdot$ E-S-QUAL $\cdot$ Online banking $\cdot$ South Africa

\section{Introduction}

Retail banking allows customers to change from one bank to the other with ease. As such, the business model of financial institutions depends on customer satisfaction realised through customer loyalty and retention [1]. Improved service quality is one such mechanism of ensuring customer satisfaction [1]. In the context of banking, service providers need to consistently meet and exceed customer expectations for both face-to-face and online banking delivery models. Consequently, customer satisfaction needs a holistic approach and banks are continuously looking for ways to attract new customers and retain existing customers. In South Africa's cash-based economy [2] meaning that a significant amount of transactions still relies on cash rather than cashless means such as money transfers and credit card services. Hence, advances in technology still need to be coupled by in-branch operational advancements as well to fully satisfy the customer base.

Wilson et al. [3] further acknowledges service quality as a major factor in gaining competitive advantage and maintaining customer satisfaction. This paper investigated the retail-banking customers' perceptions on the quality of service of online banking. The following research questions are posed in this study:

What are the perceptions of retail banking customers on the service quality of online banking as delivered by the South African banks? 
A brief background of customer satisfaction is presented followed by a discussion of the South African banking sector. The literature review discusses service quality and E-S-QUAL measurement scale. Then data collection is followed by data analysis and lastly, the paper presents the study limitations and further research ideas followed by the conclusion.

\section{Customer Satisfaction}

Customer loyalty and retention is strongly dependent on customer satisfaction especially in the services industry [4]. As such, customer satisfaction is critical in ensuring business goals are achieved. The achievement of goals the customer set out to achieve without limitations results in customer satisfaction [5], which is key to customer retention [6]. However, Rauyruen and Miller [7] identified factors that impact customer satisfaction, in addition to contextual and personal aspects, price, product quality and service quality also plays a role. According to Hallowell [8], profitability of banks depends on customer loyalty derived from customer satisfaction. Service quality, customer satisfaction, and customer loyalty in retail banking are linked together [9]. Mihelis et al. [10] linked customer satisfaction to excellence that can be applied to any organisation. Customer satisfaction requires organisations to not only match customer expectations but exceed them in order to promote customers retention [11].

\section{Retail Banking in South Africa}

South Africa is home to a number of retail banks, these include banks that are locally owned and controlled, and branches and subsidiaries of foreign banks. There are 71 banks operating in South Africa according to the South African Reserve Bank (SARB). Like in many other countries, the banking industry in South Africa is dominated by a few major banks [12] and these banks account for $89 \%$ of the market share although this has been decreasing lately [13].

The fourth industrial revolution in South Africa has revolutionise how we conduct our banking. This has led to the introduction of purely digital banks such as TymeBank, Bank Zero, and Discovery Bank, just to mention a few [14]. Columinate [15] highlighted the extent of how South Africa lags behind in online banking adoption. Online banking services consists of a variety of transactions such as checking account balances, bill payments, buying prepaid services (electricity and airtime), inter-account transfers, and new account applications, to mention but a few. Among the benefits of online banking, users identified service convenience, while security was identified as the main concern [16].

The European Union (EU) had one of the highest online banking adoption rates of $49 \%$ of the total population back in 2017 [17]. Norway had the highest rate of $93 \%$ in 2018 [18]. The Middle East and Africa have an online banking adoption rate of 8.8\%, which is far lower than the average global rate of $28.7 \%$ from 2012 data [19]. Although a higher uptake of online banking can be expected in developed countries that already have a higher internet penetration rate, the South African rate of uptake is alarmingly lower than the global average given that internet penetration rate is 54\% [20]. 
South Africa has a national policy guideline on digitisation that includes the provision of egovernment services. However, private organisations such as banks are selfregulating concerning technological advancements as these are driven by customer needs, business cases, and maintaining a competitive edge. Moreover, the South African economy is still cash-based, as the majority of the population still has no access to financial credit services [21].

\section{Service Quality}

Parasuraman et al. [22] defined service quality as the customer's perception of the degree to which the service delivered meets the customer's expectations. Parasuraman et al. [23] contends that service quality is essentially perceived quality as it comes from a comparison between actual service and expected service performance. Hence, service quality plays a critical role in maintaining an organisation's competitive edge [5]. The authors further indicated that the level of the quality of service provided had a positive effect on an organisation's financial performance. An improved competitive advantage leads to increased market share through customer loyalty [24].

There are a number of measurement models of service quality. These include SERVQUAL and SERVPERF scales for offline service quality measurement. SERVQUAL is a gap-based scale that compares customers' perceptions and expectations [25], while SERVPERF performance-based scale [26], an improvement of the SERVQUAL. In the context of South Africa, retail banks need to improve service quality based on SERVQUAL dimensions [27]. For online services, Parasuraman et al. [22] developed the E-S-QUAL and E-RecS-QUAL scales for measuring service quality in electronic service quality delivered by the electronic service provider and electronic recovery for ecommerce returns, respectively. eTailQ is used to assess the quality of retail electronic commerce [28]. The E-S-QUAL scale was chosen for this study to measure service quality in online banking, the model has been used extensively in similar settings for a number of years since the development of the scale. E-S-QUAL measurement scale has been applied in online banking across different regions including Turkey [29], Northern Cyprus [30], Australia [31], and China [32].

The original electronic service quality (E-S-QUAL) scale is a 22 -item scale consisting of four dimensions to measure online service quality. The dimensions are efficiency, fulfilment, system availability, and privacy. Efficiency measures how effective the website responds to customer needs. Fulfilment deals with timeous and accuracy of service delivery through digital channels. System availability is concerned about the system downtime, while privacy measures how the system protects customers' information. Given the increasing introduction of online services, a new scale was necessary to measure service quality delivered through online services - hence the emergence of E-S-QUAL. Kenova and Jonasson [33] developed an online banking ES-QUAL scale with these dimensions, service performance, website characteristics, communication, and efficiency. Yaya et al. [34] evaluated a number of studies that used E-S-QUAL scale and found that the scale is still relevant although some improvements are needed as technology advances, especially regarding its application in different environments. 


\section{Methodology}

The E-S-QUAL measurement scale was used in a quantitative survey research. The survey was administered through Google Forms online tool with invitations sent to potential respondents using mediums that include email, social media, and online forums. The target population and inclusion criteria were retail banking customers that use online banking in South Africa.

The demographic section of the survey collected data on four independent variables. The measurement scale items were measured based on a 5-point Likert scale that range from strongly disagree (1) to strongly agree (5). Based on convenience sampling technique, the sample came from a wide range of different income levels, qualifications, and age groups. In the end the study obtained 184 valid and usable responses from retail banking customers across South Africa. The scale used in this study is an adaptation of the original E-S-QUAL that consists of 4 dimensions and 23 statements. The statements gather customer perceptions that investigate the actual service quality experienced by customers. The adaptation was necessary to align the dimensions to online banking, as some of the original questions were deemed irrelevant in that context.

\section{Data Analysis}

Using IBM SPSS 25 statistical tool, descriptive and inferential was conducted to analyse the quantitative data. First, descriptive statistics reports on the frequencies of the biographic information provided by the respondents followed by the scale reliability test. The inferential statistical analysis section reports on group comparisons using independent samples and correlation of E-S-QUAL constructs based on demographic groups.

Table 1 shows the frequencies for each category of the variables that were included in the survey. Gender of respondents was split down the middle at 50\% each. A large proportion (40.2\%) of respondents were aged between 30-39 years, with all income groups evenly represented at around 15\% except for highest income earners group at $22.8 \%$. FNB was the most represented bank with $37 \%$ of respondents.

Experience in using online banking was measured using the number years users have been using the service, users with 5 years or more accounted for the highest percentage with $22.8 \%$, while novices those that have been using the service for less than a year accounted for $16.3 \%$. Most users access online banking once a week (45.1\%), while mobile devices are used by most used (39.1\%) followed by the use of both mobile devices and desktop computers with $36.4 \%$. 
Table 1. Descriptive statistics $(\mathrm{N}=184)$

\begin{tabular}{|c|c|c|c|c|}
\hline Variable & Category & Frequency & Percentage & Cum. Percentage \\
\hline \multirow[t]{2}{*}{ Gender } & Male & 92 & 50.0 & 50.0 \\
\hline & Female & 92 & 50.0 & 100.0 \\
\hline \multirow[t]{5}{*}{ Age } & Younger than 20 years & 9 & 4.9 & 4.9 \\
\hline & 20-29 years & 45 & 24.5 & 29.3 \\
\hline & $30-39$ years & 74 & 40.2 & 69.6 \\
\hline & $40-49$ years & 31 & 16.8 & 86.4 \\
\hline & 50 years or older & 25 & 13.6 & 100.0 \\
\hline \multirow[t]{6}{*}{ Income } & Less than R10 000 & 27 & 14.7 & 14.7 \\
\hline & R10 000-R19 999 & 26 & 14.1 & 28.8 \\
\hline & R20 000-R29 999 & 29 & 15.8 & 44.6 \\
\hline & R30 000-R39 999 & 29 & 15.8 & 60.3 \\
\hline & R40 000-R49 999 & 31 & 16.8 & 77.2 \\
\hline & R50 000 or more & 42 & 22.8 & 14.7 \\
\hline \multirow[t]{5}{*}{ Bank } & FNB & 68 & 37.0 & 37.0 \\
\hline & S. Bank & 30 & 16.3 & 53.3 \\
\hline & ABSA & 26 & 14.1 & 67.4 \\
\hline & Nedbank & 23 & 12.5 & 79.9 \\
\hline & Capitec & 37 & 20.1 & 100.0 \\
\hline \multirow[t]{3}{*}{ Experience } & Less than 12 months & 30 & 16.3 & 16.3 \\
\hline & $1-4$ years & 64 & 34.8 & 51.1 \\
\hline & 5 years or more & 90 & 48.9 & 100.0 \\
\hline \multirow[t]{3}{*}{ Use frequency } & Every day & 56 & 30.4 & 30.4 \\
\hline & Once a week & 83 & 45.1 & 75.5 \\
\hline & Once a month & 45 & 24.5 & 100.0 \\
\hline \multirow[t]{3}{*}{ Device } & Mobile device & 72 & 39.1 & 39.1 \\
\hline & Desktop computer & 45 & 24.5 & 63.6 \\
\hline & Both & 67 & 36.4 & 100.0 \\
\hline
\end{tabular}

Table 2. Lowest mean E-S-QUAL scores

\begin{tabular}{l|l}
\hline Item & Mean \\
\hline The bank's website contains just the basics and is simple to use & 3.98 \\
\hline $\begin{array}{l}\text { The bank's website does not share my personal information with other websites or } \\
\text { third parties }\end{array}$ & 3.94 \\
\hline The bank's website does not crash & 3.91 \\
\hline The bank notifies you in advance when the website will be unavailable & 3.79 \\
\hline
\end{tabular}


The mean E-S-QUAL statistics show that the overall mean for all respondents' average scores for the 23 items is 4.19 with a standard deviation of 0.762 . On face value, 4.19 out of a possible perfect score of five indicates that users are generally satisfied with the quality of service delivered by service providers.

Table 2 shows the lowest scoring questions relative to the rest of the questions in the survey that are below mean score of four. These questions show that users are unhappy with online banking websites containing more than the basic information relevant to online banking. Also of concern is the sharing of personal information provided to banks by users with third parties. The other two lowest scoring items relates to the system availability, specifically website crashing and timeous notification of system downtime.

However, further analysis is warranted to determine the statistical significance of the difference in mean E-S-QUAL values based on moderating variables that were investigated during the study. To ensure internal consistency, the scale was tested for reliability using Cronbach's Alpha. The reliability was found to be 0.969 based on the instruments' standardised items, which is acceptable as the minimum threshold for reliability is 0.70 [35]. Further reliability tests on individual constructs of the E-SQUAL measurement scale (Table 3) were also above the threshold value.

Table 3. Instrument reliability

\begin{tabular}{l|c|l}
\hline Item & No of items & Cronbach's Alpha \\
\hline Efficiency & 8 & 0.921 \\
\hline Fulfilment & 4 & 0.828 \\
\hline Privacy & 5 & 0.887 \\
\hline System availability & 6 & 0.851 \\
\hline Whole instrument & 23 & 0.969 \\
\hline
\end{tabular}

\section{Inferential Statistical Analysis}

The study collected data on moderating factors to enable the investigations based on group comparisons. The moderating factors include gender, age, income, experience, use_frequency, device, and bank. Inferential statistical analyses conducted include independent samples t-tests, one-way ANOVA, and Pearson correlation.

\subsection{Independent Samples T-Tests}

Independent samples $t$-tests allow for comparison of variables that can be categorised into dichotomous groups. Gender was the only dichotomous variable that could be analysed using independent t-tests. Hence, the hypothesis that male and female respondents have the same E-S-QUAL mean values was tested. The study conducted independent samples $t$-tests using both the Levene's test for equality of variances and the $t$-test for equality of means with a $p$-value of Levene's test of 0.347 . Given that the Levene's test is greater than the acceptable threshold of 0.05 , the study accepts the null 
hypothesis and concludes that the variance in E-S-QUAL values for males and females was equal. Hence, the difference was statistically insignificant, which meant that we had to consider the output of equal variance assumed in order to test for equality of means.

\subsection{One-Way ANOVA}

One-way ANOVA means analysis of variance was performed for variables with more than two groups to determine the significance of statistical differences in mean values. F denotes the test statistic for one-way ANOVA. Table 4 provides one-way ANOVA F- and $p$-values, including post hoc tests for group comparisons.

The findings show that the mean E-S-QUAL values for different groups in the variables age, experience, income, and use_frequency have no significant differences. This is because the significance ( $p$ values) are all above the 0.05 threshold. Hence, the study accept the null hypothesis that the means are not different.

The results also show that there was some significant difference in the mean values based on the respondents' bank as indicated by $F$ value of 3.644 at 0.007 significance level $(p<0.01)$. However, the differences are not significant when comparing each bank against the other based on multiple comparisons that showed no significant $p$ values both at 0.01 and at 0.05 level. This implies that users' perceived service quality is influenced by the bank of choice but no significant influence when comparing each of the investigated banks against each other.

Table 4. One-way ANOVA: E-S-QUAL mean scores

\begin{tabular}{l|l|l|l|l|l}
\hline Factor & df & F & Sig. & $\begin{array}{l}\text { Post hoc tests (multiple } \\
\text { comparisons) }\end{array}$ \\
\hline Age & 4 & 0.585 & 0.674 & None & $p>0.05$ \\
\hline Experience & 2 & 1.171 & 0.312 & None & $p>0.05$ \\
\hline Income & 5 & 0.625 & 0.681 & None & $p>0.05$ \\
\hline Use frequency & 2 & 1.999 & 0.138 & None & $p>0.05$ \\
\hline Bank & 4 & 3.644 & 0.007 & None & $p<0.05$ \\
\hline Device & 2 & 9.253 & 0.000 & $\begin{array}{l}\text { Mobile vs both } \\
\text { PC vs both }\end{array}$ & $p<0.05$ \\
\hline
\end{tabular}

The choice of device between mobile, desktop computer, or both devices indicated that E-S-QUAL values depends on the device of choice - with $F$ value of 9.253 at 0.000 significant level $(p<0.01)$. Multiple group comparisons, both comparisons between mobile device vs both devices and PC vs both devices showed significant means difference at the 0.05 level. Hence, the device used to access online banking has influence on how the user perceives the quality of service delivered by the bank. 


\subsection{Correlations}

To determine the strength and direction of relationships between the dependent variable E-S-QUAL values and independent moderating variables Pearson correlation analysis was conducted. The Pearson correlation is a number between -1 and +1 that indicates the degree of the relation among two or more variables. Table 5 has correlation analysis results with the relations that are noted for discussion formatted in bold, as they are significant at 0.05 level.

Pearson correlation values that are below 0.3 are considered weak, between 0.3 and .05 are moderate with 0.5 to 1 considered strong [35]. Using this interpretation, Table 5 has only four moderate relationships as follows: age-income, income-experience, income-use_frequency, and income-device. A positive coefficient means that there is a direct relation between the two variables, meaning that as one variable increases, the other increases [36]. Age-income have a moderate positive relationship, meaning as age of users increases so does their income. The same trend is noted for both incomeexperience and income-device relations. High-income earners tend to make use of both mobile and desktop computer to access online banking and are generally more satisfied with the service quality. On the other hand, the relations between incomeuse_frequency have a moderate negative relationship. This implies that as income increases the frequency at which users access online banking decreases. Interestingly, only device has any notable correlation with E-S-QUAL mean values, that is, a very weak positive relationship. This leads to the conclusion that E-S-QUAL is not influenced by any of the variables investigated since no medium or strong relationships exist at 0.05 level, albeit a very weak one with device. The rest of the bold relationships in Table 5 are weak and no strong relationships exists.

Table 5. Correlation between moderating variables

\begin{tabular}{|c|c|c|c|c|c|c|c|}
\hline & & Gender & Age & Income & Experience & Use frequency & Device \\
\hline \multirow[t]{2}{*}{ Gender } & Pearson correlation & 1 & & & & & \\
\hline & Sig. (2-tailed) & & & & & & \\
\hline \multirow[t]{2}{*}{ Age } & Pearson correlation & -.031 & 1 & & & & \\
\hline & Sig. (2-tailed) & .681 & & & & & \\
\hline \multirow[t]{2}{*}{ Income } & Pearson correlation & $-.264^{* * *}$ & $.420^{* * *}$ & 1 & & & \\
\hline & Sig. (2-tailed) & .000 & .000 & & & & \\
\hline Experience & Pearson correlation & -.059 & $.262^{* * *}$ & $.468^{* *}$ & 1 & & \\
\hline \multirow[t]{2}{*}{ Use frequency } & Sig. (2-tailed) & .427 & .000 & .000 & & & \\
\hline & Pearson correlation & $.213^{* *}$ & .131 & $-.311^{* * *}$ & $-.253^{* *}$ & 1 & \\
\hline \multirow[t]{2}{*}{ Device } & Sig. (2-tailed) & .004 & .076 & .000 & .001 & & \\
\hline & Pearson correlation & $-.156^{*}$ & $.167^{*}$ & $.407^{* *}$ & $.251^{* * *}$ & $-.291^{* * *}$ & 1 \\
\hline & & .034 & .024 & .000 & .001 & .000 & \\
\hline
\end{tabular}




\section{Limitations and Further Research}

The E-S-QUAL scale need updating as electronic service quality has evolved since 2005 the year of its first introduction. For instance, the scale is heavy on infrastructure reliability in meeting customer needs. The scale lacks emphasis on new aspects in online customer satisfaction such as user experience and electronic satisfaction. These can be considered for further research to assist in the evolution of E-S-QUAL. A larger sample would also make the generalisation of findings across the whole population of online banking users. This also allows the reporting to include bank names without unwarranted prejudice. Further research is needed to also include current aspects such as user experience of online banking that affect customer satisfaction and provide a holistic service quality assessment. Also of consideration as future work is a qualitative study that investigates new constructs by asking online banking users what services they need, instead of an evaluation of the currently provided services. Moreover, measurements based on customer perceptions are highly subjective, which requires some caution in generalisation of such findings.

\section{Conclusion}

E-S-QUAL essentially measures the extent to which online users are satisfied with the service quality delivered by the service provider. The study analysed the mean E-SQUAL values to determine the existence of any significant differences in mean scores across moderating variables. The average mean E-S-QUAL scores for individual respondents across the sample showed that users are generally satisfied with the service quality of online banking. The exception were four questions that had mean scores of below four with two lowest scores concerning system availability. Inferential statistical results show that there are insignificant differences in mean scores based on independent samples $t$-tests, one-way ANOVA, and Pearson correlation analyses. Using Levene's test, gender showed no statistical significance, as this was the only variable with dichotomous values. One-way ANOVA tests identified the variable device as the only variable that has influence on E-S-QUAL scores, while all other variables tested had no influence customers' perceptions of online banking service quality. This suggest banks need to offer online banking through a variety of devices, in order to optimise service quality to improve customer satisfaction.

Overall, the study accept the null hypothesis and concludes that the difference in ES-QUAL mean values are statistically insignificant for all moderating variables. This means banks can take holistic approaches in improving service quality that does not target specific demographic groups but the whole customer base in addressing service

quality problems. The significance of electronic service quality measurement is to identify areas for improvement and encourage wide usage of digital channels. Especially, considering huge investments financial institutions are making in digital channels. This allows for higher return on investment on digital solutions while reducing inbranch operational costs for banks. 


\section{References}

1. Rahman, M.S., Khan, A.H., Haque, M.M.: A conceptual study on the relationship between service quality towards customer satisfaction: servqual and Gronroos's service quality model perspective. Asian Soc. Sci. 8(13), 1227-1232 (2012)

2. Hull, E., James, D.: Introduction: popular economies in South Africa. Ocean Coast. Manag. 82(1), 1-19 (2012). https://doi.org/10.1017/SOOO1972011000696

3. Wilson, A., Zeithaml, V.A., Bitner, M.J., Gremler, D.D.: Services Marketing: Integrating Customer Focus Across the Firm, 3rd edn. McGraw Hill, London (2012)

4. Oliver, R.L.: Whence consumer loyalty? J. Market. 63(1999), 33-44 (1999). https://doi.org/ $10.2307 / 1252099$

5. Paul, J., Mittal, A., Srivastav, G.: Impact of service quality on customer satisfaction in private and public sector banks. Int. J. Bank Mark. 34(5), 606-622 (2016). https://doi.org/10. 1108/ijbm-03-2015-0030

6. Kottler, P., Keller, K.L.: Marketing Management, 15th edn. Pearson Pretice Hall, New Jersey (2016)

7. Rauyruen, P., Miller, K.E.: Relationship quality as a predictor of B2B customer loyalty. J. Bus. Res. 60(1), 21-31 (2007). https://doi.org/10.1016/j.jbusres.2005.11.006

8. Hallowell, R.: The relationships of customer satisfaction, customer loyalty, and profitability: an empirical study. Int. J. Serv. Ind. Manag. 7(4), 27-42 (1996). https://doi.org/10.1108/ 09564239610129931

9. Ngo, V.M., Nguyen, H.H.: The relationship between service quality, customer satisfaction and customer loyalty: an investigation in Vietnamese retail banking sector. J. Compet. 8(2), 103-116 (2016). https://doi.org/10.7441/dokbat.2016.43

10. Mihelis, G., Grigoroudis, E., Siskos, Y., Politis, Y., Malandrakis, Y.: Customer satisfaction measurement in the private bank sector. Eur. J. Oper. Res. 130(2), 347-360 (2001). https:// doi.org/10.1016/s0377-2217(00)00036-9

11. Hoffmann, A.O.I., Birnbrich, C.: The impact of fraud prevention on bank-customer relationships: an empirical investigation in retail banking. Int. J. Bank Mark. 30(5), 390-407 (2012)

12. BusinessTech: Battle of the banks: how SA's big five banks compare. https://businesstech. co.za/news/banking/182873/battle-of-the-banks-how-sas-big-five-banks-compare/. Accessed 5 Apr 2018

13. Fin24: Big five SA banks losing market share. https://www.fin24.com/Companies/FinancialServices/big-five-sa-banks-losing-market-share-20160525. Accessed 5 Apr 2018

14. IT Web: Digital newcomers to disrupt South African banking. https://www.itweb.co.za/ content/kLgB1MeJbZXq59N4. Accessed 20 Feb 2019

15. Van Zyl, G.: FNB rated SA's 'top internet banking provider. http://www.fin24.com/Tech/ News/FNB-rated-SAs-top-internet-banking-provider-20150507. Accessed 20 Nov 2017

16. Mujinga, M., Eloff, M.M., Kroeze, J.H.: Online banking users' perceptions in South Africa: an exploratory empirical study. In: Proceedings of IST-Africa 2016 Conference, Durban, South Africa, 11-13 May 2016, pp. 1-7 (2016)

17. Statista: Online Banking Penetration in Selected European Markets in 2016. https://www. statista.com/statistics/222286/online-banking-penetration-in-leading-european-countries/.

Accessed 20 Nov 2017

18. Statista. Online banking penetration in Norway from 2005 to 2018. https://www.statista. com/statistics/380892/online-banking-penetration-in-norway/. Accessed 20 Feb 2019 
19. Statista: Global online banking penetration in April 2012, by region. https://www.statista. com/statistics/233284/development-of-global-online-banking-penetration/. Accessed 6 Nov 2017

20. Internet World Stats: Internet World Stats. http://www.internetworldstats.com/stats.htm. Accessed 15 Aug 2017

21. Maziya, M., Zwane, T.: Financial inclusion is more than just access to credit. https://mg.co. za/article/2017-11-03-financial-inclusion-is-more-than-just-access-to-credit. Accessed 20 Feb 2019

22. Parasuraman, A., Zeithaml, V.A., Malhotra, A.: E-S-QUAL - a multiple-item scale for assessing electronic service quality. J. Serv. Res. 7(3), 213-233 (2005). https://doi.org/10. $1177 / 1094670504271156$

23. Parasuraman, A., Zeithaml, V.A., Berry, L.L.: A conceptual model of service quality and its implications for future research. J. Mark. 49(Fall 1985), 41-50 (1985). https://doi.org/10. 1177/002224298504900403

24. Siu, N.Y., Mou, J.C.: Measuring service quality in internet banking: the case of Hong Kong. J. Int. Consumer Market. 17(4), 99-116 (2005). https://doi.org/10.1300/j046v17n04_06

25. Parasuraman, A., Zeithaml, V.A., Berry, L.L.: SERVQUAL: a multiple-item scale for measuring consumer perceptions of service quality. J. Retail. 64(1), 12-40 (1988)

26. Cronin Jr., J.J., Taylor, S.A.: Measuring service quality: a reexamination and extension. J. Mark. 56(3), 55-68 (1992). https://doi.org/10.2307/1252296

27. Mujinga, M.: Retail banking service quality measurement: SERVQUAL gap analysis. In: 2019 Conference on Information Communications Technology and Society (ICTAS), Durban, South Africa, 6-8 March 2019, pp. 1-6 (2019)

28. Wolfinbarger, M., Gilly, M.C.: eTailQ: dimensionalizing, measuring and predicting etail quality. J. Retail. 79(3), 183-198 (2003). https://doi.org/10.1016/s0022-4359(03)00034-4

29. Akinci, S., Atilgan-Inan, E., Aksoy, S.: Re-assessment of E-S-Qual and E-RecS-Qual in a pure service setting. J. Bus. Res. 63(3), 232-240 (2010)

30. Karatepe, O.M., Yavas, U., Babakus, E.: Measuring service quality of banks: scale development and validation. J. Retail. Consum. Serv. 12(5), 373-383 (2005). https://doi.org/ 10.1016/j.jretconser.2005.01.001

31. Herington, C., Weaven, S.: E-retailing by banks: e-service quality and its importance to customer satisfaction. Eur. J. Mark. 43(9/10), 1220-1231 (2009). https://doi.org/10.1108/ 03090560910976456

32. Sun, Q., Wang, C., Cao, H.: Applying ES-QUAL scale to analysis the factors affecting consumers to use internet banking services. In: 2009 IITA International Conference on Services Science, Management and Engineering, Zhangjiajie, China, 11-12 July 2009, pp. 242-245 (2009)

33. Kenova, V., Jonasson, P.: Quality online banking services. Jonkoping International Business School (2006)

34. Yaya, L.H.P., Marimon, F., Casadesús, M.: The expert experience in adopting the ES-QUAL scale. Total. Qual. Manag. Bus. Excel. 28(11-12), 1307-1321 (2017). https://doi.org/10. 1080/14783363.2015.1135728

35. Pallant, J.: SPSS Survival Manual: A Step by Step Guide to Data Analysis using IBM SPSS, 5th edn. McGraw-Hill Education, Berkshire (2013)

36. Antonius, R.: Interpreting Quantitative Data with IBM SPSS Statistics, 2nd edn. Sage Publications, London (2013) 